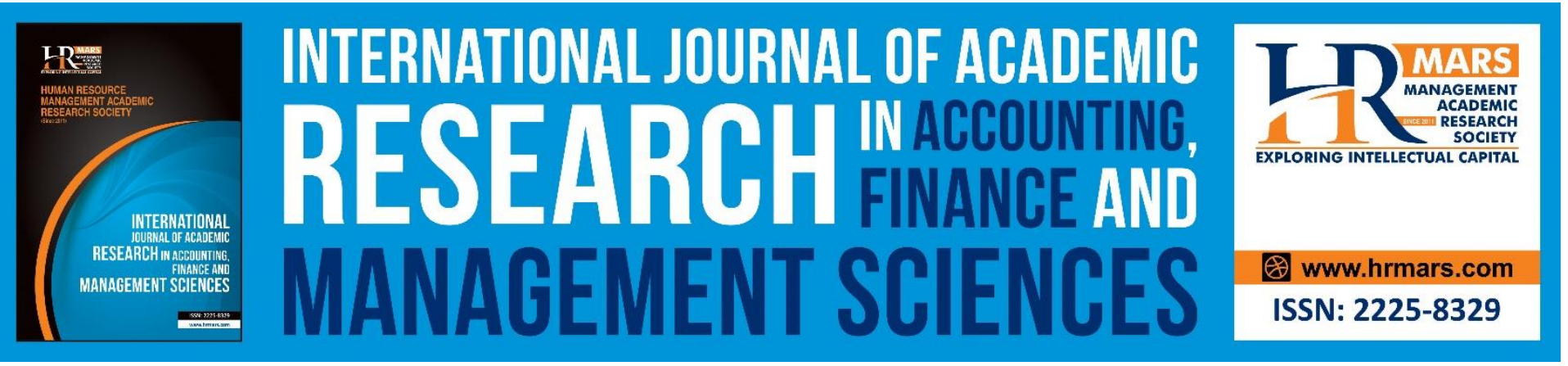

\title{
E-Commerce: Advantages and Limitations
}

\section{Ghada Taher}

To Link this Article: http://dx.doi.org/10.6007/IJARAFMS/v11-i1/8987

DOI:10.6007/IJARAFMS /v11-i1/8987

Received: 30 December 2020, Revised: 21 January 2021, Accepted: 15 January 2021

Published Online: 28 February 2021

In-Text Citation: (Taher, 2021)

To Cite this Article: Taher, G. (2021). E-Commerce: Advantages and Limitations. International Journal of Academic Research in Accounting Finance and Management Sciences, 11(1), 153-165.

Copyright: (C) 2021 The Author(s)

Published by Human Resource Management Academic Research Society (www.hrmars.com)

This article is published under the Creative Commons Attribution (CC BY 4.0) license. Anyone may reproduce, distribute, translate and create derivative works of this article (for both commercial and non-commercial purposes), subject to full attribution to the original publication and authors. The full terms of this license may be seen

at: http://creativecommons.org/licences/by/4.0/legalcode

Vol. 11, No. 1, 2021, Pg. 153 - 165

http://hrmars.com/index.php/pages/detail/IJARAFMS

JOURNAL HOMEPAGE

Full Terms \& Conditions of access and use can be found at http://hrmars.com/index.php/pages/detail/publication-ethics 


\title{
E-Commerce: Advantages and Limitations
}

\author{
Ghada Taher \\ Department of Business Administration, Beirut Arab University, Beirut, Lebanon \\ Email: tahir.ghada45@gmail.com
}

\begin{abstract}
Electronic commerce plays an essential role in advancing information technology as well as communication. This is particularly true in the realm of the economy. In the age of globalizing economics, many markets have become progressively international and competitive. Even as the covid-19 pandemic further leads industries in heavily impacted areas to insource towards local production as global trade was blocked, e-commerce can aid the economy on a local scale. Furthermore, improvements on the internet, along with advancements in information technology, and the progress in logistics and deliveries have enabled nearly every business to buy, sell and liaise on a global scale. This has led to the unexpected interest in electronic commerce in societies. However, although e-commerce has dominated the marketplace, online services and trade, bring on various benefits as well as major key drawbacks.

This paper sheds light on the key features of e-commerce and the drawbacks it brings on two, the organization as well as customers. Well, understanding the benefits and drawbacks is essential as a benefit for the customer might be translated into a drawback for the business organization. Prosperous business organizations are very aware of the benefits and drawbacks before venturing into any business decision. The paper concludes, Despite the disadvantages of e-commerce, the numerous advantages of this business manage to successfully attract the attention of both companies and customers. Technology is evolving tremendously, so it is possible to witness the prevention of technological defects in particular in the near future.
\end{abstract}

Keywords: Electronic Commerce, E-Commerce, Advantages, Disadvantages, Economy, Benefits, Drawbacks

\section{Introduction}

Recently, electronic commerce has become very popular around the world with many advanced technologies presented in its process. E-commerce was established in the $1960 \mathrm{~s}$ as business organizations implemented the usage of Electronic Date Interchange (EDI) as a tool to exchange data with other business organizations. In 1979, sharing documents through electronic networks for businesses was established universally. The usage of electronic networks for business continued to witness an increase in the 1980s until it boomed in the 1990s when online market platforms eBay and Amazon surged. Purchasing limitless amounts of items online from e trailers has become 
INTERNATIONAL JOURNAL OF ACADEMIC RESEARCH IN ACCOUNTING, FINANCE AND MANAGEMENT SCIENCES

Vol. 11, No. 1, 2021, E-ISSN: 2225-8329 @ 2021 HRMARS

available to all consumers (Khurana, 2019). Today electronic commerce is thought of as phenomenal as its powerful concept and processes have profoundly changed the present life. For many, business electronic commerce has become a priority (Nanehkaran, 2013; Abdulaali et al., 2019). Electronic commerce has opened doors to business organizations. It provided them with opportunities to further improve and advance prevailing market position by delivering an inexpensive, more operational distribution sequence for their products and/or services (Abbas et al., 2021). The usage of electronic commerce has also provided business organizations the capability of connecting with corresponding business organizations in order to reduce producton and delivery times following the Toyota managing system, also known as "Just in time production" and "just in time delivery". Utilizing e-commerce and following the Toyota production system yields a business a globally competitive position. The internet has become prevalant worldwide on all levels whether personal or business. Taking advantage of the establishment of the internet worldwide yields chances for reducing costs, generating revenue, advertising, marketing, and even accessing the market. In addition, it provides a chance to improve customer service via straightforward contacts, facilitating time fast enquiries and response. Customers have been allowed to effortlessly reach the world market on the cybernetic economy, a world rich in varied items for customers to choose from with ease. Furthermore, ecommerce has given a chance for unindustrialized nations to grow and obtain a greater status in the systematics of the world of trade. This is mainly true as electronic commerce assissts underindustrialized economies maximise their trade profits, giving them more room to grow (Dan, 2014). As a whole, Internet commerce simplified the break-through that provided an enormous boost for transnational trade. Electronic trade will bring permanent and total alteration to the world of trade. The biggest alterations will be tangible in underindustrialized countries since they have the biggest room for develeopment. Internet commerce can be the instrument for those countries to reduce expenditures, enhance productivity, and save time and distance. As Big Commerce cites, "ecommerce is growing $23 \%$ year-over-year, and according to marketer, global ecommerce sales are expected to top $\$ 27$ trillion in 2020 - and that's just statistics for the retail sector." Therefore, in this paper, we will take a deep look at the meaning of electronic commerce, explore its types, and will shed lights on the advantages and limitations of this type of trade.

E-commerce has become a fundamental dynamic of the economy over the years. Its ability to allow businesses to extend to a wider consumer range, as well as its ability to allow customers to shop at their convenience, has contributed to its growth and significance. The practicality of e-commerce has led it to become the fastest-growing retail market. The covid-19 health pandemic has further contributed to the development of e-commerce. As more people forgo socialization and resort to social distancing, isolation, quarantine, or avoiding public places or crowded areas, customers have turned to a convenient platform to make purchases, the online market. Thus, the overall number of customers, returning and first-timers has prevailed (Halan, 2020). As the covid-19 pandemic is expected to linger into the future, it is proportionally expected that the e-commerce market witnesses additional enhancement. A study has found that with the current situation, consumers are more likely to seek safety and convenience. Based on the study, these traits and habits are likely to drag into the post-pandemic period and the study estimated that e-commerce could reach 300 to 350 million shoppers by the financial year 2025 (Bain \& Company, 2020). Furthermore, a survey by (UNCTAD, 2020) found that the pandemic has resulted in a sales growth of e-commerce websites. The stock shares invested in traditional trade have become at risk and are witnessing a decline 
concurrent with the spread of COVID-19, and this will be a strong reason for the willingness of each trader of these traditional markets to move towards trade via the internet in order to preserve the rest of its shares and maintain its commercial field and market success. Therefore, understanding the dynamics including the advantages and disadvantages, of e-commerce is elemental.

\section{Definition of Electronic Commerce}

Internet trade has been acknowledged and studied by specialists, students, and researchers since it was initialized. There are multiple definitions for e-commerce as defined by scholars, researchers, and authors. Limitation was not attribute to their definitions of electronic commerce. This portion of the articile will state various characterizations for e-commerce as well as the researcher's as mentioned by (Chahar et al., 2013).

According to Jamsheer (2019), e-commerce is the usage of telecommunication networks to automate business relations and workflow. On the other hand, (Bristol, 2001) strongly claims that e-commerce is the conduction of trade in products and anemities, under the assistance of telecommunication and telecommunication centered instruments. Moreover, (Rose et al., 2019) contends that e-commerce refers to the exchanging organization data, preserving business relations, and conducting operational transactions via telecommunication systems. Ultimately, (Kalakota \& Whinston, 1997; Abdullah et al., 2021) characterizes e-commerce as utilizing computer, internet, and shared software technology to exchange merchandise descriptions and illustrations; offers and procurement details; as well as other information needed to be conversed to consumers, providers, staffs, or the community.

\section{Types of Electronic commerce}

A number of classifications of electronic commerce exist. Academics determined a number of outlines for classifying electronic commerc; each illustrated from a unique viewpoint. As a result, e-commerce can be classified as follows (Clarke, 1999).

\section{B2B (Business to Business)}

This process takes place as a company sells services to another company. For instance, a supplier puts in a request with a business organizaitons website. Upon, receiving goods, the supplier then retails them to the final consumer. Forrester Research estimated that the business to business electronic commerce would surpass 1 trillion USD in the united states before the year 2021. This type of ecommerce would report for over \%12 business to business sales nationwide (Rose et al., 2019). 


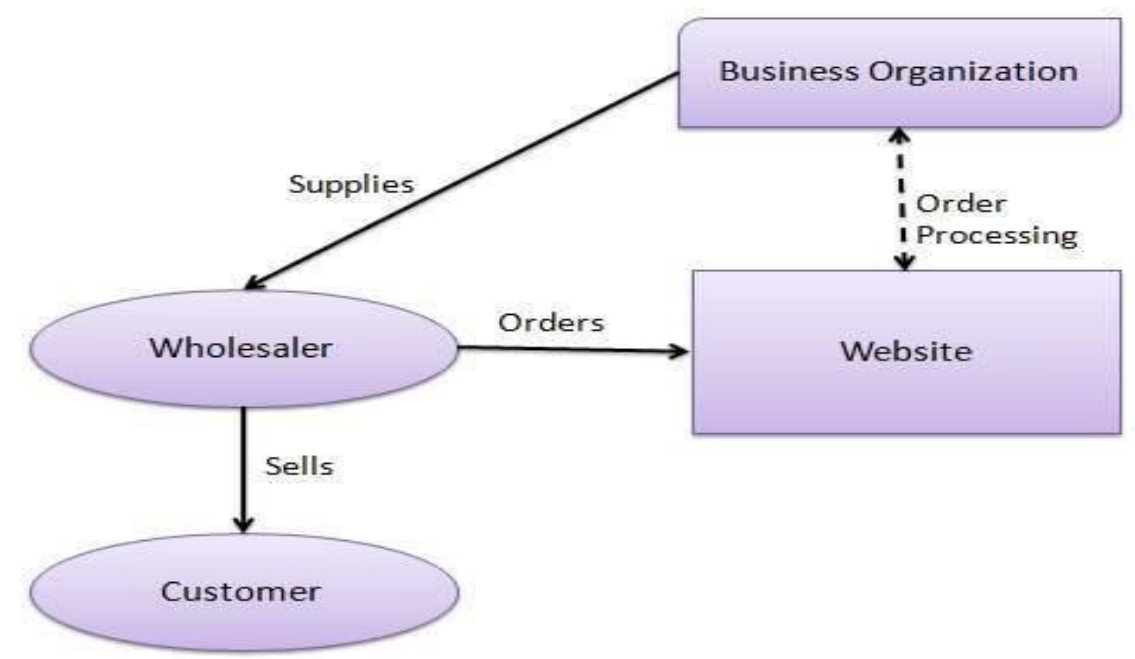

Figure 2 Business to Business model (B2B)

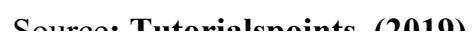

\section{B2C (Business to Customers)}

This is when a business organization retails products or amenities to an individual consumer. The individual consumer sees the items posted on the web page. Then, the consumer chooses an item and orders it. Following an order, the web page automatically forwards an order request to the company and the company processes the order and delivers the order to the consumer. The business organization which has dominated this type of ecommerce (B2C) is the Amazon marketplace.

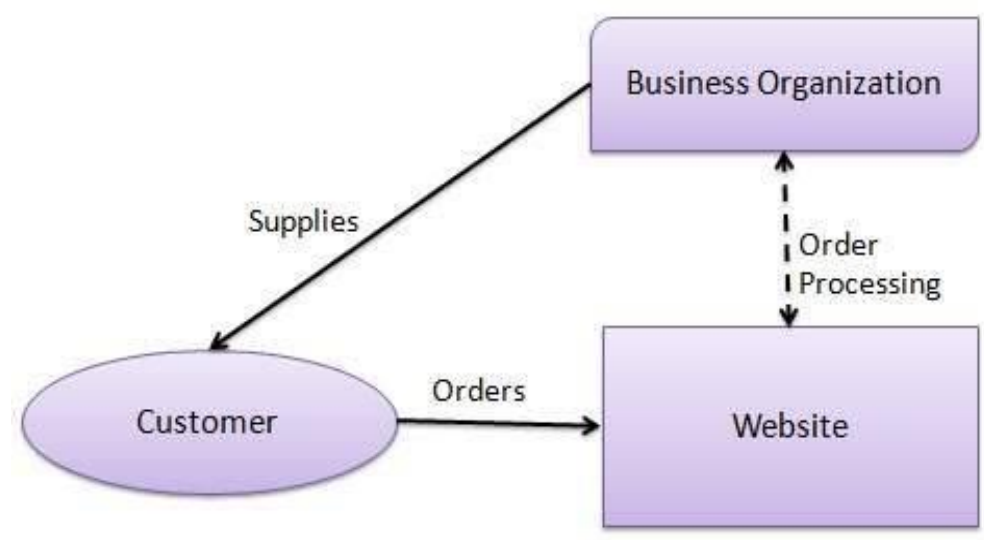

Figure 3 Business to Customer Model (B2C)

Source: Tutorialspoints, (2019) 
INTERNATIONAL JOURNAL OF ACADEMIC RESEARCH IN ACCOUNTING, FINANCE AND MANAGEMENT SCIENCES

Vol. 11, No. 1, 2021, E-ISSN: 2225-8329 @ 2021 HRMARS

\section{C2C (Customer to Customer)}

This is when a consumer sells a good or services to another consumer. For example, a person sells a car on e-bay to another person, or even rents a space by posting their info on a designated webpage. The purchase is performed when another consumer buys the product after seeing the advert on the webpages like ebay or craigslist. Consumers in this type of business model deal in business directly with each other.

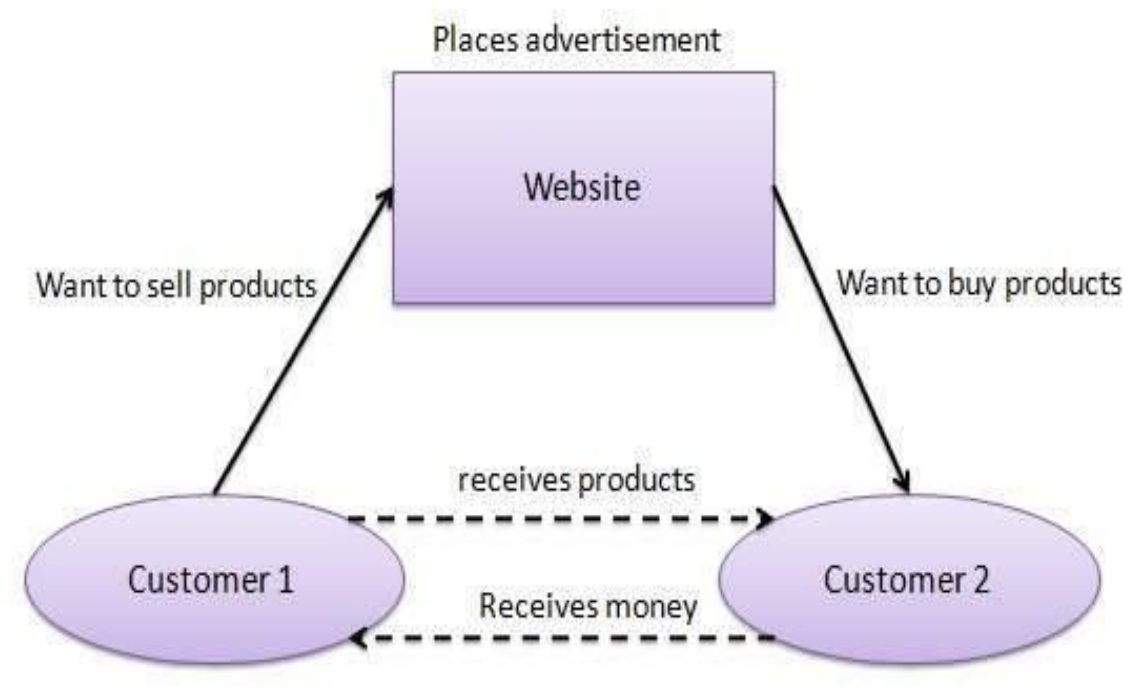

Figure 4 Customer to Customer Model (C2C) 
INTERNATIONAL JOURNAL OF ACADEMIC RESEARCH IN ACCOUNTING, FINANCE AND

MANAGEMENT SCIENCES

Vol. 11, No. 1, 2021, E-ISSN: 2225-8329 @ 2021 HRMARS

\section{C2B (Customer to Business)}

This kind of business happens when a consumer sells their own goods or services to a business or organization (Al-Abrrow and Alnoor, 2017). Sometimes, it is a business model where users generate products or services that are used by business and institutions. For example, a photographer can license their photo for a business to use.

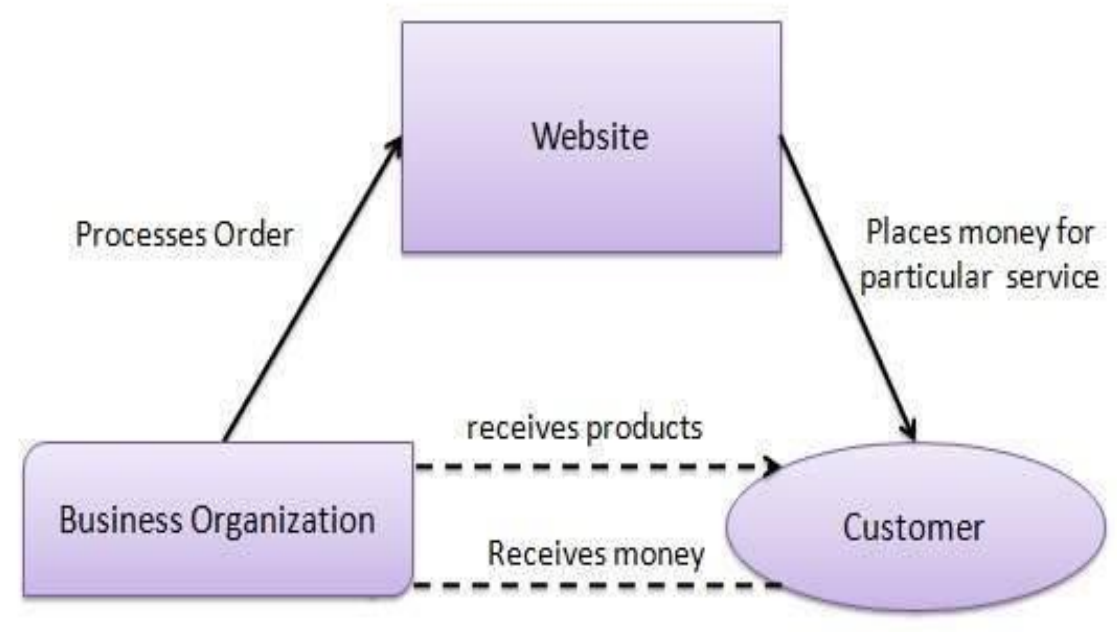

Figure 5 Customer to Business Model (C2B)

Source: Tutorialspoints, (2019)

\section{B2A (Business to Administration)}

Business to administration is defined as business to government electronic trade. In B2A, a business uses a major webpage to send and receive data, as well as conduct business, with governmental agencies. The online business exchange is more proficient. A few examples of this kind of business are legal documentation, employment and social security.

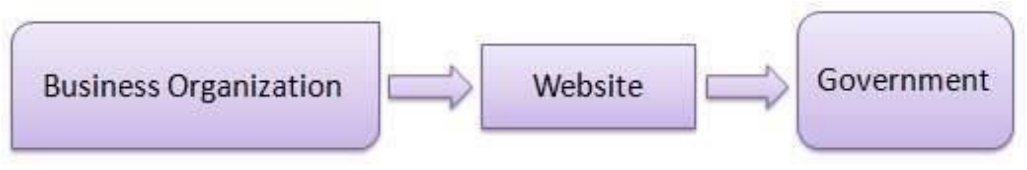

Figure 6 Business to Administration Model (B2A)

\section{C2A (Customers to Administrations)}

The last kind of category of e-commerce business is customer to administration or customer to government electronic trade. It aids individuals to demand data or place different comments concerning public subdivisions straight to the administration or governmental establishments. As an example, electric bills, health insurance fees/payments, and taxes all go under this category. This type of model is considered an easy way for consumers to communicate with the governments straightaway. 


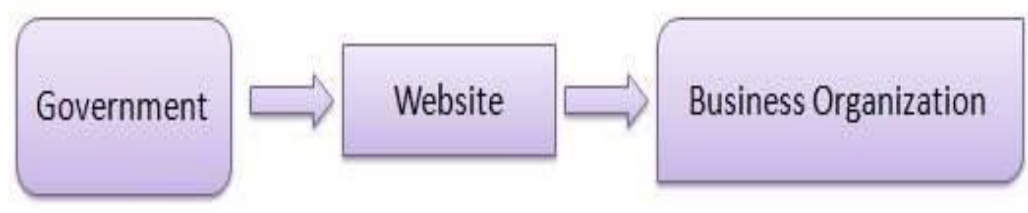

Figure 7 Customers to Administrations (C2A)

Source: Tutorialspoints, (2019)

\section{The advantages of E-commerce}

Recently, there has been a noticeable rise in the percentage of online shopping. With more customers, this percentage has been increasing as time goes by. Customers, organizations, as well as the society are getting great benefits from E-Commerce. To illustrate, in the past years when traditional marketing systems used to prevail, customers wasted lots of time and energy commuting to the physical shops to do their conventional shopping. With the advent of e-marketing, customers can give up on the usual exhausting trip to the supermarket to purchase the desired goods. With the web-enabled computers, laptops or mobile devices, shopping is much easier. This unconventional shopping allows customers to do shopping everywhere while sitting comfortably in their house (Aonerank, 2019). Now, the question remains in why we notice such an interest in online transactions?

The rise of interest in online shopping has a bunch of reasons. The most common one is the fact that this shopping is enjoyable for both customers and merchants. It is called a win-win situation where both parties are getting benefits. Below is a summary of classification of e-commerce benefits as listed by Franco, et al. (2016).

\section{The main classifications for the benefits of e-commerce}

- Advantage to the customer

- Advantage to the organization

- Advantage to the society

\section{Benefits of E- commerce to the customers.}

\section{Buying 24/7 all year long}

E-commerce stores are available at all times. Customers can shop at all hours of any day during the year. In this case, customers, especially those who do not usually have time on their hands to do conventional shopping, can do any purchase anytime through visiting the website. Such websites facilitate shopping due to their convenient design. For example, products are classified into categories which help customers have fast orders. Moreover, this kind of shopping is perfect for people who work long hours and are unable to find time to go to retail shops (Aonerank, 2019; Khurana, 2019; Al-Abrrow et al., 2018). A good example of such websites are AmazonFresh, Target, and Walmart. 
INTERNATIONAL JOURNAL OF ACADEMIC RESEARCH IN ACCOUNTING, FINANCE AND

MANAGEMENT SCIENCES

Vol. 11, No. 1, 2021, E-ISSN: $2225-8329$ @ 2021 HRMARS

\section{Convenience}

Being a very convenient way to do shopping, E-commerce has become the easiest and most popular way for shopping. Products can be ordered anywhere on the planet with just a simple tap on the mobile device connected to the Internet (Aonerank, 2019). With such an easy way, consumers effortlessly pick merchandise from various sources with no physical constraint.

\section{Time Saving}

Time is money! With the benefit of being fast, E-commerce has facilitated the buying/selling procedures. A key advantage of cyber shops is saving time. In other words, while shopping online, customers would not need more than 15 minutes to perform their purchase. Add to that, providers are so careful as to deliver the products to customers' doorsteps within a week.

\section{Comparison in prices}

With E-commerce platforms, consumers are provided with more opportunities to see different price points and features and thus pick less expensive and superior options (Clarke, 1999). Comparing choices in a conventional or physical marketing system can be very difficult, since visiting all the stores and asking for prices can be exhausting to the customers. The issue of asking about prices can be a little embarrassing for some customers, and some others do not even dare to ask about the price of a certain item. However, with online shopping, everything is tool to hand and clear in front of users.

\section{Adequate information}

E-Commerce provides a history of customers' purchases available whenever needed with a huge amount of data. A customer does not only see the relevant detailed information within seconds, but is also able to review his/her previous purchases (Clarke, 1999). Therefore, it permits clients to search for merchandise info, compare the costs and benefits and eventually evaluate its value before performing the purchase. This is very difficult to be seen in a conventional shop since such a vast amount of data is difficult and sometimes impossible, to be displayed to customers.

Many options and range (options \& options)

E commerce has broad array of merchandises and amenities, consumers can get to see a varied choice of products and services to chose the best of them, unlike traditional marketing system, one can see only a limited stock McKinsey \& Company, (2019).

\section{Accessible}

In a normal conventional store, customers might get lost while wandering from aisle to other browsing for merchandise. However, with e-commerce services, clients can search the merchandise categories, or they take advantage of the webpage's search tool and can, in no time, find the desired product (Searchcio, 2019).

\section{Benefits for the companies No Geographical Limitations}

Conventional shops impose limitations on providers which are always costly and inaccessible. For example, if customers need to get a certain item from Beirut and they live in Tripoli, they will have to 
drive and waste more money in order to get what they need. Similarly, if merchants want to display their products in another city, they will have to open new branches and pay extra money and exert extra efforts. With the electronic commerce these kinds of limitations have no place to be found (Jamsheer, 2019). By utilizing e-commerce, businesses can magnify their marketplace to countrywide and world-wide marketplaces with least money investing. In other words, an company can effortlessly find additional clienteles, top dealers, and appropriate corporate associates throughout the world (Clarke, 1999).

\section{Money Saving}

E- Commerce business have significantly lower operational costs and better quality of services, in comparison to the actual stores. There is no staff to employ and recompense, no rent and has a reduced fixed operating expenditure (Aonerank, 2019).

\section{Increasing efficiency of companies}

E-commerce benefits from the "pull" type supply administration. In this type of management, a business procedure begins at the moment a demand originates from a client and utilizes a 'just in time manufacturing' method. This makes the company conduct business transactions faster and at lower operational costs, increading company efficiency.

\section{Laser targeting market}

Targeting the right people is a key factor in promoting e-commerce services. Online providers collect a great amount of consumers' data to ensure they are targeting the right audience to their products. For instance, if they are promoting a male-oriented product, they are capable of targeting one sex and getting more engagements, and as results gaining more purchases. Same is the case with promoting other customized services for different age groups.

\section{Easy to initiate and administer a company}

Location is an issue which an e-commerce business owner never worries about in running a business. All is required are electronic devices such as laptops or mobile phones and Internet connection. Therefore, e-commerce simplifies the business processes with more speed and efficiency.

\section{Higher Ad returns}

It helps organizations gain higher return on advertisements, if managed properly.

\section{Advantages for the Society (Clarke, 1999).}

Customers do not need to move from one place to another to do their shopping. This process results in less transportation on streets and reduced air pollution.

It reduces the pricepoint range of items due to less fixed expenditures, so consumers with lower incomes are also able to buy items.

It has allowed remote zones in the countryside to contact items and anemities that were not accessible previously. 
It aids governments in delivering communal services. For example, medical charges, schooling fees, and communal service industries can be obtainable to citizens with less cost and more developed method.

\section{The disadvantages of E-commerce}

Like any other business where there are always ups and downs, E-commerce has benefits and drawbacks. Running this kind of business has its own challenges. However, being aware of such challenges will help people in charge of this business avoid common consequences. The e-commerce downsides can be classified into two main categories: technical and nontechnical.

\section{Non-technical disadvantage}

Inability to test items first-hand before buying

It is one of the most common problems faced while shopping online. With this kind of shopping, customers are unable to try the item before getting it (Alhamdi et al., 2019; AL-Abrrow et al., 2020). In another sense, e-commerce takes away a crucial part of the purchase process which is testing the product. Videos promoting the products might have been made in a very professional and convincing way, but still many customers are hesitant to buy any item they have not tested or seen before. This is so due to the fact that many customers do not see a real guarantee of product quality.

\section{Lack of the personal touch}

E-commerce is missing one of the factors that many customers consider to be essential, which is the personal touch. In other words, some consumers need to feel the intimate experience from physically going to the store and and interrelating with sales assistants. So, with online shopping there is no place for new relationships to be born (Searchcio, 2019; Al-Abbrow et al., 2019; Alnoor, 2020).

\section{Delay in delivery}

Waiting is one of the online shopping features, which turns into a problem if customers are not patient enough. To shop online means to wait up to one week, or sometimes more, to have your order in your hands. The gratification anyone gets while doing actual shopping is always delayed while shopping online where customers do not hold the physical item in their hands for a while after the procurement (Bhasin, 2019).

\section{Cost and product feature comparison}

Through cyber shopping, buyers can liken several items and catch the cheapest cost. While shoppers love being able to compare prices, providers find it too restrictive as numerous prices are eliminated from suggested or recommended items based on the price range the customer sets.

\section{Damage during Transportation and Delivery}

The product bought online can be damaged or spoiled during delivery.

\section{Restricted Consumer Services}


In the case that a consumer has any enquiries about a certain item in a physical shop, the assistant, the cashier or even the store manager all are ready for help. In contrast, the customer service on ecommerce websites can be restricted: the site may only offer services at a specific work schedule, and sometimes a call to the consumer services division may place the consumer on callhold for a long time (Khurana, 2019; Alnoor et al., 2020).

\section{Technical Disadvantages}

\section{Security issue}

Cyber security is a worldwide issue which needs to be resolved. Eventually, the lack of reliable security systems creates a risky experience for customers shopping online. In recent years, the world has witnessed a number of reputable organizations and international businesses falling targets of scammers which steal consumer data from their databank. This could result in lawful and monetary allegations. Likewise, it also deforms the confidence which took years to be built between the customers and their providers.

\section{Need for Internet Connection}

Connectivity to the web or online access is required for the partaking of customers in online shopping. They also require devices that connect to the Net (Bhasin, 2019).

\section{Credit card Fraud}

One of the real and growing problems in the world of online businesses is credit card fraud. It can consequence in the forfeiture of profits, fines, and bad repute. Both customer and the business are easy preys to credit card deception. Some pessimists even to claim that scams will eventually result in the vanishing of e-commerce (Chahar et al., 2013).

\section{Software development}

Software is constantly being developed and modified. This poses limitations on online companies. For example, it requires companies to constantly update software as well as hardware required to support the development of software.

\section{Conclusion}

A significant amount of studies and analysis have been conducted on the topic of e-commerce. Electronic commerce has extended quickly throughout the decade and is expected to further expand at this speed or faster. In the forthcoming period, the limits amid "conventional" and "electronic" trade will become progressively distorted as more and more companies transfer segments of their operations online. Electronic trade will undoubtedly increase significantly in the coming years (Sharp, 1998). Despite what was mentioned earlier in this paper about the technical and non-technical disadvantages of e-commerce, the numerous advantages of this business manage to successfully attract the attention of both companies and customers. As we have already mentioned technology is evolving tremendously and quickly, so it is possible to witness the prevention of technological defects in particular in the near future.

It is also worth not to forget that today there is a new generation of influencers who are soon to make their touches on the future of e-commerce. For example, individuals belonging to Generation Z- 
individuals born between 1995 and 2010 - have reached the workplace and are bringing change and challenges with them. These people are true digital natives for they have been exposed to the internet, social networks, and mobile phones since a very young age. Moreover, those members prefer remote work and favor flexible work conditions. They prefer to work in remote areas and do the jobs that rely mostly on technology. So in short, electronic commerce is the future.

\section{References}

Abbas, S., Hadi, A. A., Abdullah, H. O., Alnoor, A., Khattak, Z. Z., \& Khaw, K. W. (2021). Encountering Covid-19 and perceived stress and the role of a health climate among medical workers. Current Psychology, 1-14.

Abdulaali, A. R., Alnoor, A., \& Eneizan, B. (2019). A multi-level study of influence financial knowledge management small and medium enterprises. Polish Journal of Management Studies, 19(1):2131

Abdullah, H., Ismail, I., Alnoor, A., \& Yaqoub, E. (2021). Effect of perceived support on employee's voice behaviour through the work engagement: a moderator role of locus of control. International Journal of Process Management and Benchmarking, 11(1), 60-79.

Al-Abrrow, H., and Alnoor A. (2017). The Impact of Locus of Control and Relationship Quality in Counterproductive Work Behavior Through Trust in the Leader and Psychological Empowerment: An Empirical Study on Workers in Public Hospitals in Basra. Jordan Journal of Business Administration, 13 (2) .201-231.

Al-Abrrow, H., \& Alnoor, A. (2017). The impact of locus of control and relationship quality in counterproductive work behavior through trust in the leader and psychological empowerment: An empirical study on workers in public hospitals in Basra. Jordan Journal of Business Administration, 13(2), 201-231.

Al-Abrrow, H., Ali, J., \& Alnoor, A. (2019). Multilevel Influence of Routine Redesigning, Legitimacy and Functional Affordance on Sustainability Accounting: Mediating Role of Organizational Sensemaking. Global Business Review, 0972150919869726.

AL-Abrrow, H., Al-Maatoq, M., Alharbi, R. K., Alnoor, A., Abdullah, H. O., Abbas, S., \& Khattak, Z. Z. (2020). Understanding employees' responses to the COVID-19 pandemic: The attractiveness of healthcare jobs. Global Business and Organizational Excellence.40(2):19-33

Al-Abrrow, H., Alnoor, A., \& Abbas, S. (2019). The Effect of Organizational Resilience and CEO's Narcissism on Project Success: Organizational Risk as Mediating Variable. Organization Management Journal,16(1) 1-13.

Al-Abrrow, H., Alnoor, A., \& Abbas, S. (2019). The effect of organizational resilience and CEO's narcissism on project success: Organizational risk as mediating variable. Organization Management Journal, 16(1), 1-13.

Al-Abrrow, H., Alnoor, A., \& Abdullah, H. (2018). Socio-Technical Approach, Decision-Making Environment, and Sustainable Performance: Role of ERP Systems.Interdisciplinary Journal of Information, Knowledge, and Management. (13). 397-415.

Alhamdi, M., Alnoor, A., Eneizan, B., Abdulla, M., \& Abdulaali, A. R. (2019). Determinants of the production system time (jit) on reduce waste: Case study in a salsal water company. International Journal of Academic Research in Business and Social Sciences, 9(7), 17-32. 
INTERNATIONAL JOURNAL OF ACADEMIC RESEARCH IN ACCOUNTING, FINANCE AND

MANAGEMENT SCIENCES

Vol. 11, No. 1, 2021, E-ISSN: 2225-8329 ๔ 2021 HRMARS

Alhamdi, M., Noor, R. M. A. S., Abdulla, M., Alnoor, A., \& Eneizan, B. (2019). How does financial analysis influence the firm's failure of Iraqi private sector?. The Journal of Social Sciences Research, 5(9), 1321-1328.

Alnoor, A. (2020). Human capital dimensions and firm performance, mediating role of knowledge management. International Journal of Business Excellence, 20(2), 149-168.

Alnoor, A. M., Al-Abrrow, H., Abdullah, H., \& Abbas, S. (2020). The impact of self-efficacy on employees' ability to accept new technology in an Iraqi university. Global Business and Organizational Excellence, 39(2), 41-50.

Aonerank. (2019). Benefits of e commerce for customers, digital marketing learning. Available: https://www.aonerank.com/digital-marketing-learning/benefits-ecommerce-customers/.

Bhasin, H. (2019). 16 Disadvantages of E-commerce - Problems with E-commerce. Available:https://www.marketing91.com/disadvantages-of-e-commerce/.

Bristol, A. M. (2001). The impact of electronic commerce on tax revenues in the caribbean community. Regional Tax Policy Administration Unit. Georgetown Guyana, SA.

Clarke, R. (1999). Electronic Commerce Definition. Available: http:/www.rogerclarke.com.

Dan, C. (2014). Electronic Commerce: State- Of -Art. American journal of intelligent system. Beijing University of Technology, 4(4), 135-141.

El Gawady, Z. M. (2005). The Impact Of E-Commerce On Developed And Developing Countries: Egypt And United States. Misr university of science and technology. Gizza, egypt.

Jamsheer, K. (2019). Impact Of E-Commerce On Society: Advantages And Disadvantages. Available: https://acowebs.com/impact-ecommerce-society/.

Kalakota R., \& Whinston A.B. (1997). Electronic Commerce: A Manager's Guide, Addison-Wesley.

Khurana, A. (2019). Introduction To E-Commerce. Available: http://www.ddegjust.ac.in/studymaterial/mcom/mc-201.pdf

McKinsey \& Company. (2019). 'True Gen': Generation Z And Its Implications For Companies. Available: $\quad$ https://www.mckinsey.com/industries/consumer-packaged-goods/ourinsights/true-gen-generation-z-and-its-implications-for-companies

Nanehkaran, A. Y. (2013). An introduction to Electronic Commerce. International Journal Of Scientific \& Technology Research,2 (4).

Reevs \& sons. (2019). E-commerce definition. What is ecommerce?. Available:https://ecommerceplatforms.com/glossary/ecommerce

Sharp, B. (1998). Creating An E-Commerce Architecture, Unix review, 47(2), 45-51.

Tutorialspoints. (2019). E-Commerce- Business Models. Available:https://www.tutorialspoint.com/e_commerce/e_commerce_business_models.htm.

Vladimir, Z. (1996). Electronic Commerce: structure and issues. International Journal of Electronic Commerce Research, VOL.1 (1), PP 3-23.

Wat, F. K. T., Ngai, E. W. T. (2000). A Literature Review And Classification Of Electronic Commerce Research. Information \& Management, 39, 415-429.

Wong, L. (2017). E-Commerce Advantages And Disadvantages. Available: https://blog.apruve.com/ecommerce-advantages-and-disadvantages.

World trade organization (2013).E-Commerce For Developing Countries. Available: https://www.wto.org/english/res_e/booksp_e/ecom_brochure_e.pdf. 
INTERNATIONAL JOURNAL OF ACADEMIC RESEARCH IN ACCOUNTING, FINANCE AND MANAGEMENT SCIENCES

Vol. 11, No. 1, 2021, E-ISSN: 2225-8329 @ 2021 HRMARS 